\title{
PHUTAI ETHNIC TEXTILE INTERPRETATION AND THE ADAPTIVE USING OF MEKONG MICE TRAVELERS
}

\author{
Donruetai Kovathanakul \\ Faculty of Business Administration and Accountancy, Khon Kaen University, Thailand
}

\begin{abstract}
This article "Phutai Ethnic Textile Interpretation and the adaptive using of MICE Travelers" is a part of research plan "Adaptive Using Local Textiles Guidelines for Creative Cultural Heritage Tourism Development", and a research plan of "Mekong Ethnic Groups Tourism Development, Based on the Authenticity, to Support ASEAN Tourism Plan". The objectives are 1) studied and analyzed the context of Phutai ethnic textile interpretation and the adaptive using of Mekong MICE travelers; 2) to proposed the concept of Phutai Ethnic adaptive using guideline for ethnic textile interpretation. Related literature was reviewed: ethnic textile, interpretation, adaptive using, and MICE travelers. Field research, interviews, and surveying was extracted. The guideline of Phutai Ethnic textile adaptive using of Mekong MICE travelers was proposed.
\end{abstract}

Keywords: Phutai, Ethnic Textile, Interpretation, Adaptive Using, MICE Travelers

\section{INTRODUCTION}

Local textiles are one part of the cultural heritage. The unique characteristics of local textiles depend on their areas and cultural significance. Local textiles are not only based on physical forms, but can also include intangible values, such as cultural identity, local wisdom, a body of knowledge, and beliefs. As cultural resources, local textiles can be used in community development through tourism. Moreover, they can also be used as a tool in tourism interpretation. With its diversity, local textiles are suitable for creating innovations. This means local textiles can be used for improving, developing, and creating added value, as well as for integrating with other knowledge.

The current study is a part of research project on "The Guideline Application of Local Textile towards Creative Cultural Heritage Tourism Development". The study area was in the educational area in Northeastern Thailand which is well known for Mudmee silk, Kit-weaving, and Hang kra rok silk (Adapted from: www.kanchanapisek.or.th). These textiles represent the unique identity of Thai wisdom.
However, when searching for Intangible Heritage in the UNESCO, 2007 database, there was no information related to Thai precious Intellectual cultural heritage. This paper has aimed to study Thai local textile interpretation with respect to the adaptation of its valuable use with tourists as the target group.

Tourists are important stakeholders in the economy. According to a study by Pongsiri (2003), it was revealed that Thai tourists tend to buy souvenirs in the form of fabrics, while foreign tourists favor scarves and shawls. It can be seen that the tourists behaviors of both Thais and foreigners differ. Hence, the adaptation should be applied based on each tourist group by using principles of marketing. Niche Market will contribute to income distribution in the community which will result in tangible economic values.

For the abovementioned reasons, the researcher has conducted research on "Phutai Ethnic Textile Interpretation and the Adaptive Using of Mekong MICE Travelers", so as to publicize the heritage of 
Thai cultural wisdom by offering interpretations to Thai and foreign tourists, especially MICE travelers and by adapting culture to increase the value of creative economics.

\section{OBJECTIVES}

1. To study and analyze the context of Phutai ethnic textile interpretation and the adaptive use of Mekong MICE travelers.

2. To propose the concepts and guidelines of Phutai Ethnic textiles and adapt their use for ethnic textile interpretation.

\section{RELATED LITERATURE}

\section{Ethnic Textile and Adaptive Use}

Most of Thai local textiles are produced from two types of natural yarns which are silk and cotton. There are differences in local production in terms of colors, the processes of dyeing \& weaving, textures, and stitching with other materials (Ministry of University Affairs, 1998). There are different characteristics between Local textiles made of silk and cotton. Textiles made from silk are more durable, but the process to produce silk yarn is more difficult than producing cotton yarn. As a result, silk is normally used for special occasions, in traditional ceremonies, or in worship ceremonies, while cotton is used in daily life (Silpakorn University, 2001: 40-41).

Since Thai local textiles, which are handicrafts, differ according to the local context and can specify the cultural identity of the community in the area (Woodikarn, 2001). In addition, local textiles also indicate the social status of the people who are using them. (Silpakorn University, 2001: 40).

Thai local texture can be categorized into 5 main types based on the weaving process, the fineness of the texture, the usage, and the mixture of the textures (Silpakorn University, 2001).

Kit-weaving, which is mostly found in Northeastern Thailand, has been inherited from the Laos, Phutai, and Tai Lue ethnic groups. In the weaving process, a thin piece of wood with one sharp end is used as a tool for creating texture. The thin wood is used to pull the silk up or push it down by counting each silk yarn until the texture is completed.

Mudmee, which is also found in the Northeast, has been inherited from Laos, Phutai, and Khmer ethnic groups. In the dyeing process, in order to create texture, some parts of the materials are tied up with a rope. With respect to the parts, that have been tied up, they will have no color when the texture is woven.

Praewa can be seen in the Northeast and has been inherited from the Phutai ethnic group. Khid, the patterned weaving process, was used to produce Praewa. Each fabric contains a variety of textures. Each texture was woven in levels with different colors. People, who produce Praewa, always have a sample of the texture while weaving.

The Competitiveness Development Office and the Office of the National Economic and Social Development Board (2006) have systematized cluster mapping into groups. In the Northeast, there are two effective groups which are:

1. Developing Group: Ban Siew Noi silk production network, Chaiyapum Province

2. Seeking Direction Group: Indigo fabric, Sakon Nakhon Province and silk production, Pak Thong Chai District. There are also other Thai local textiles that were called differently.

From the past, weaving textiles was normally produced for household or community use, rather than used for marketing purposes. However, at present, people prefer to use fabrics produced from industry process more than handmade textiles (Wuttatrakul \& Phanyura, 1994). As a result, there is a lack of continued development of local Thai textiles. There is no conscientious inheritance and the number of specialists has also decreased. In addition, factors regarding the influence of the Royal culture and cosmopolitan culture (Ministry of University Affairs, 1998: 15), including a lack of education about Thai local textiles and their applications, have contributed to the disappearance of Thai local textiles which are considered to be a cultural heritage. According to an area based survey by Silpakorn University in 2001 (Silpakorn University, 2001: 227), 
the results showed that problems and obstacles related to Thai local textile were as follows:

1. There is a lack of attentiveness in weaving work among people who make a living from weaving. Also, identity inheritors or conservators are lacking. Nonetheless, authentic weaving arts are rarely found.

2. There is a lack of strong association in each area. Therefore, the effectiveness of production and production plans are low. In addition, the bargaining power of the community is low and the plans for setting a direction for marketing was also inefficient.

3. There is a lack of product development and new designs. There are no varieties of products that meet market needs.

4. There is a lack of market for product distribution. The price of the product was also lowered by the middleman.

5. There is a lack of sustainable support from relevant sectors in terms of sources of funds, production techniques, marketing, and promoting products.

At present, most of people, who are making a living by producing Thai local textiles, were ethnic groups who had settled in new places or had fled due to war. Textiles from different ethnics groups have been inherited from local habitats. The diversity of cultural identity in Thailand can be seen through different techniques and methods.

Pook (2002) has classified textiles in to three types according to their usages: 1) textiles for everyday use, 2) textiles for special occasions, and 3) textiles used for religious ceremonies. This classification focuses upon clothing.

The development of the Thai textile industry is under the strategic plan and master plan to increase competitiveness. In the textile and clothing industry (2007-2011), it was seen that projections, that direct and carry out the strategic plan, had been conducted during a time when the economic and world markets were growing well with world economic growth at an average of $5.2 \%$ and $3.4 \%$ in 2007 and 2008, respectively. In 2008, textile and clothing industries in the world's exporting market were worth 560,277 million US Dollars, increasing from the past year by $7.5 \%$. As a result of the strategic drive under the vision that empowered Thailand to become the center of textile and fashion in ASEAN region, there were innovations, improvements, and the establishment of the center of textiles, so as to compel and facilitate private organizations to conduct research, develop a variety of products, develop labor efficiency, and to develop textile clusters both at the central and regional levels, including supply chain development in ASEAN market. As a result, Thailand's competitiveness has remained at a satisfactory level. In 2008, Thailand received a market share from world's textile and clothing export, ranging from 12th to 13th, respectively, with a total export value of 7,200 million US Dollars (Textile Development Center, 2011).

Currently, there are different ways of applying Thai textiles. For example, the Institute for Small and Medium Enterprises Development (2013) has given an example for applying Thai textiles, such as the production of Thai textile dolls or luxuriously decorated pictures focusing on characters from Thai literature. The renowned fabric production company named Jim Thompson (The Thai Silk Company, 1951) has also applied Thai textiles in production design, such as bags and pen cases.

In Thailand, the Textile Development Center (2011) mentioned that weaving products have been applied in 12 different fields of industries, such as Agricultural, Construction, Geology, Industry, Medical, Automotive, Packaging, Protection, Sports, Household, Environment, and Clothing.

\section{INTERPRETATION}

Interpretation is an educational activity which aims to reveal meaning and relationships through the use of original objects, by first-hand experience, and by illustrative media, rather than simply to communicate factual information (Tilden, 1957). Interpretation is not an instruction, but a motivation for readers or audience members to motivate their interests and knowledge towards factual understanding. Interpretation is set behind the fact which was revealed through techniques (Gove, 1963), thoughts, 
or the transference of feelings from one person to another, and through the appropriate use of gestures, facial expressions, words, written language, television, telephone, and radio, etc. (Good, 1973). These bring meaning to environmental resources, enhance visitor appreciation, promote better understanding through experiences, and deepen people's understanding of people, events, and objects from past and present (Association for Heritage Interpretation, 1975). As a result visitors are more likely to care for and have conservative mindset towards the development of sustainable tourism. Show in Figure 1.

\section{MICE Travelers}

The MICE industry consists of Meetings, Incentive Travel, Conventions, and Exhibitions. The following are details of MICE (Convention and Exhibition Bureau, 2013).

"MICE Travelers": The factor that differentiates MICE travelers from other tourists, who travel for leisure, is the expenditure per traveler. Data from many countries, including Thailand, showed that the expenditure of MICE travelers per person has almost doubled as compared to people who travel for leisure. (For example, in Thailand, when comparing the expenditure of tourists in 2011, it was seen that general tourists spend 37,000 1 Baht per person per trip while MICE travelers spend 80,000 Baht per person per trip.2). This shows that MICE travelers are high quality travelers and deserve to be given no less priority than tourists who travel for leisure (http://tourisminvest.tat.or.th, 2016).

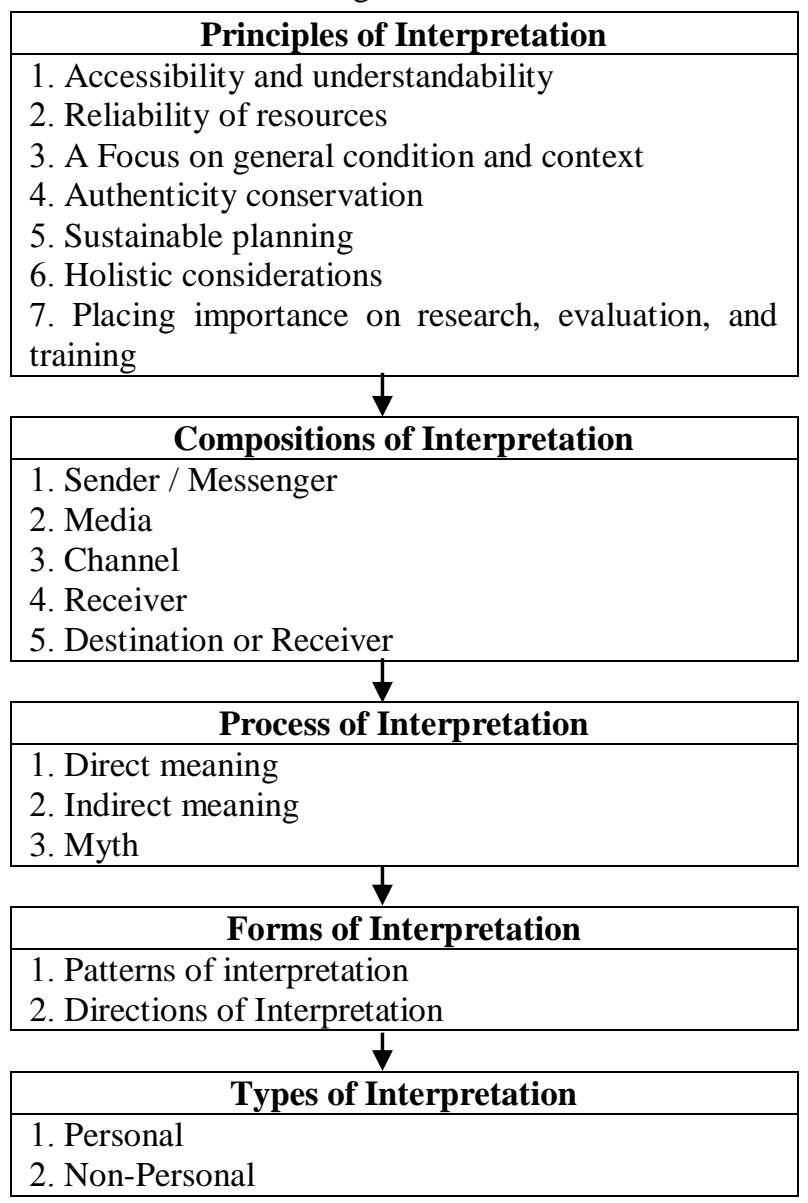

Figure 1 Interpretation Process Framework

\section{RESEARCH METHODOLOGY}

From Table 1, the instruments used to evaluate this investigation included the following: 1) surveys (used in surveying the area of Phutai Ethnic Group in
Thailand), and 2) Interviews (used to collect data from relevant sectors and individuals involved in tourism). Content Validity Index: CVI was verified by 9 specialists. The result of content Validity Index was CVI $=0.981-0.989$ which meant these 


\section{Alum}

\section{Dyeing tones}

- Brown/Black/White/Green/Blue/Red/Violet

Dye:

- Natural colors

\section{Dyeing process:}

- Place 20 Liters of water, 3 kilograms of bark, and 200 grams of alum into a container. (Alum is added to make the color more permanent and the textiles brighter.)

- Hot dye is filtered through a cloth in the container that is prepared for dyeing process.

- The prepared textile is shaken for flatness, and then soaked in the container. The textile, being dyed, is stirred with a stick so that the colors can be absorbed in the fabric until get the desired color of the textile is reached.

- The dyed textile is washed with clean water (The darker color is prepared by boiling the dyed textile with dye solution again until get the desired color is reached. Then the dyed textile is rinsed with clean water).

\section{Patterns}

- Small patterns

- Mi Pla pattern

- Mi Tum pattern

- Mi Kra Jung pattern

- Mi Kho pattern

- White and black Madmee cotton

(Julaju, 2008)

\section{The Weaving process}

- The unbleached cotton thread is bought locally or in other provinces.

- The cotton is bleached and starched.

- Cotton yarn is spun and stretched for loom preparation.

- The cotton yarn is attached to the loom. The size of loom depends upon the width of textile.

- The cloth is woven and designed into a variety of products by cutting each piece to 1.50 meters. After that, the textile is cleaned before taking it for the dyeing process.

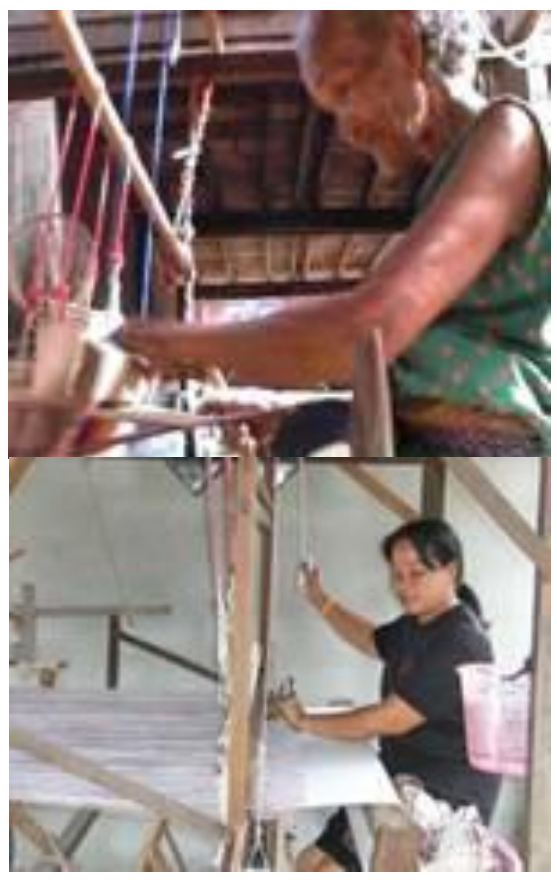

Figure 2 Textile Weaving

\section{Textile Processing}

The Development of Shawl Processing: Hand-made cloth patterns from the Phu Tai tribe, Waistbands, and Sarongs are designed to meet the market's needs. In this process, the natural dye and the folk wisdom are preserved.

\section{Price}

The local textiles are woven and dyed with natural dyes at the rate of approximately 1,500 -2,000 sheets per month. The price is around 50-100 Baht.

\section{Distribution Channels and Duration}

- Distributed at 65 Moo.8 Tumbol Kud Wa Amphur Kuchinarai, Kalasin Province.

- Pre-ordering from customers by telephone

- Selling at exhibitions together with government service

\section{Marketing Promotion}

- OTOP (One Tumbol One Product)

- Website: www.otoptoday.com and www.thaitambon.com 


\section{Interpretation}

\section{Knowledge \& Local Wisdom}

- Hand-made cloth pattern is a form of the Phu Tai ethnic group. Waistbands and Sarongs are made of natural cotton which is durable, ventilated, and comfortable.

- Dyeing with Natural Dyes: If desired, textiles can be soaked in fabric softener to give softness and a nice smell.

- Drying Dyed Clothes: Clothes should be dried in the shade. If clothes are dried directly in the sunlight, the colors will be different and unattractive.

\section{Media of Interpretation}

Local Textile Products from Khok Kong Village in Kalasin Province

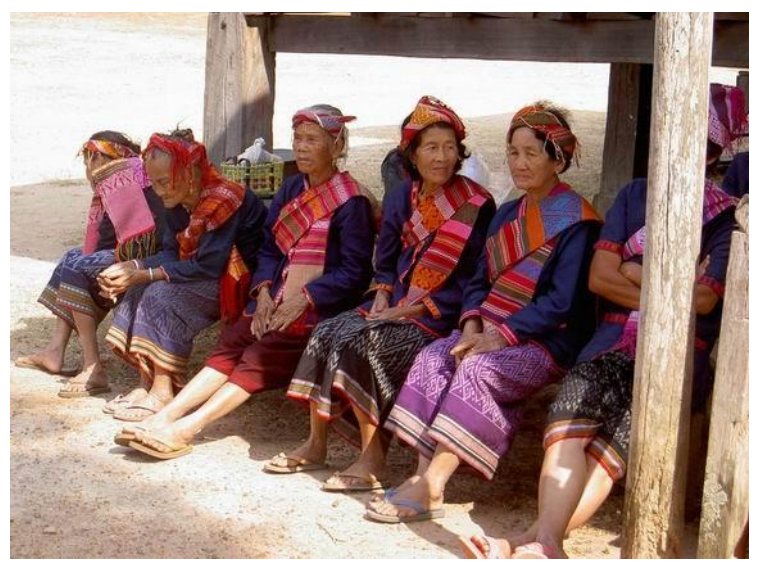

Figure 3 Styles of Phutai Textiles

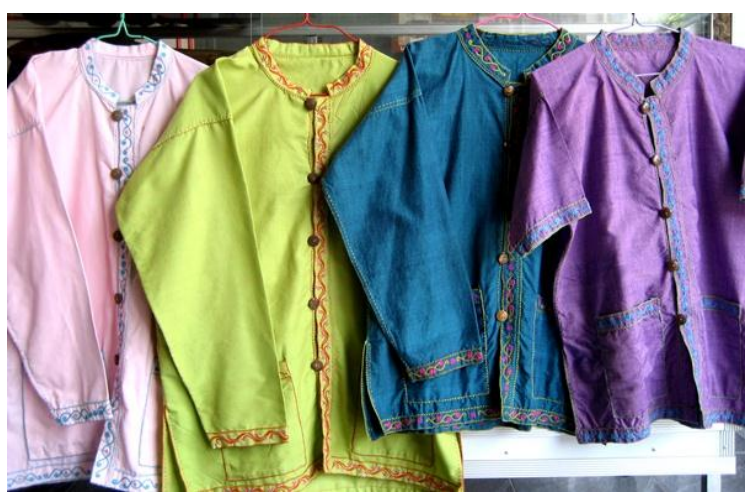

Figure 4 Cotton Shirts

Figure 6 A Display of Phutai Products
(Tourism Authority of Thailand, n.d.)

Figure 6 A Display of Phutai Product
(Tourism Authority of Thailand, n.d.)

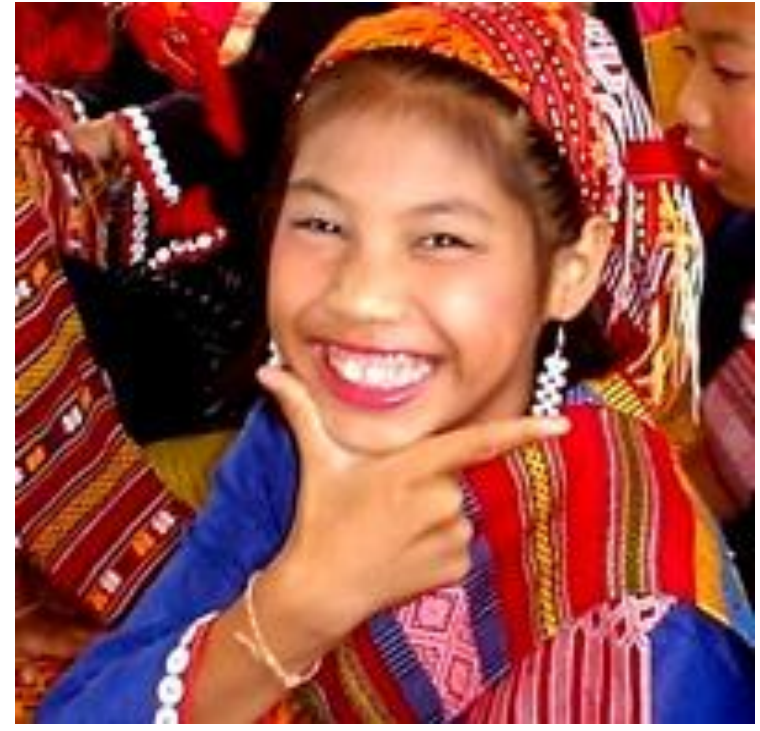

Figure 5 A Phutai Headband

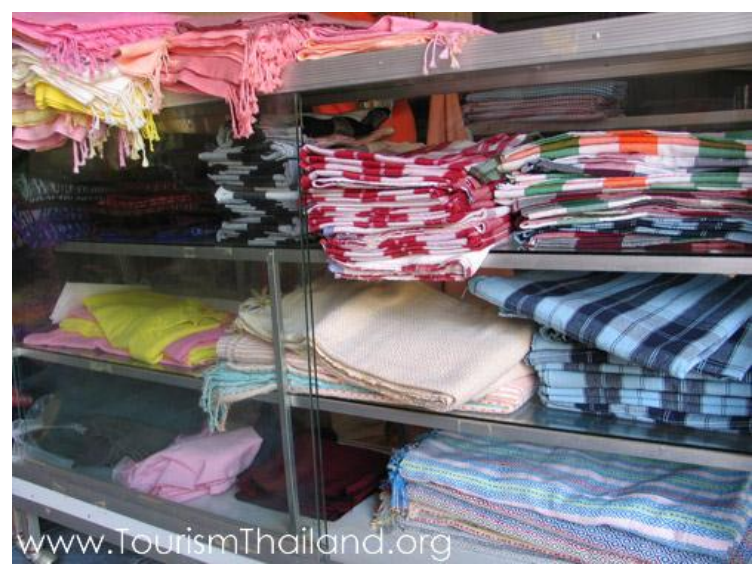




\section{Level of Satisfaction re: Local Textile Products with New Designs from designers}

Table 2 Level of Satisfaction re: Local Textile Products with the New Design from Designers in terms of Structure

\begin{tabular}{|c|c|c|c|}
\hline Structure & Mean & S.D. & Level of Satisfaction \\
\hline 1. Pattern is easy to produce. & 3.58 & 1.056 & High \\
\hline 2. Products are convenient for transportation. & 3.70 & 1.040 & High \\
\hline 3. Products are easy to carry. & 3.88 & 0.998 & High \\
\hline 4. Products have different designs than the market. & 4.06 & 0.952 & High \\
\hline 5. Production period & 3.82 & 0.968 & High \\
\hline Total & 3.81 & 0.878 & High \\
\hline
\end{tabular}

Note: A Mean score of 4.21-5.00 refers to the highest level of satisfaction. 3.41-4.20 refers to a high level of satisfaction. 2.61-3.40 refers to a moderate level of satisfaction. 1.81-2.60 refers to a low level of satisfaction. 1.00-1.80 refers to the lowest level of satisfaction
According to Table 2, it was seen that respondents were satisfied the local textile products with the new patterns from designers in terms of structure at high level, with the mean score of 3.81. The importance of other minor factors in other parts was also high with mean scores of $3.58,3.70,3.88,4.06$ and 3.82 , respectively.

Table 3 The Level of Satisfaction re: Local Textile Products with the New Designs from Designers in terms of the Value of Art \& Aesthetics

\begin{tabular}{lccc}
\multicolumn{1}{c}{ Ve the Value of Art \& Aesthetics } \\
\multicolumn{1}{c}{ Value of Art \& Aesthetics } & Mean & S.D. & Level of Satisfaction \\
\hline 1. Products are delicate. & 3.77 & 1.014 & High \\
2. Products have beautiful shapes. & 3.91 & 1.026 & High \\
3. The use of colors is appropriate. & 3.92 & 0.971 & High \\
4. The patterns represent the life style of the villagers. & 3.89 & 0.973 & High \\
5. Products show the identity of the province. & 3.79 & 1.113 & High \\
6. Product can attract tourists. & 4.06 & 0.952 & High \\
\hline Total & 3.89 & 0.891 & High
\end{tabular}

Note: Mean score 4.21-5.00 refers to the highest level of satisfaction. 3.41-4.20 refers to a high level of satisfaction. 2.61-3.40 refers to a moderate level of satisfaction. 1.81-2.60 refers to a low level of satisfaction. 1.00-1.80 refers to the lowest level of satisfaction.
From Table 3, the results showed that the respondents were satisfied the local textile products with the new design from designer in terms of the value of art and aesthetics at high level with the mean score 3.89. Other minor factors in other parts were also at the level of high satisfaction with mean scores of 3.77 , $3.91,3.92,3.89$ and 4.06, respectively.

Table 4 The Level of Satisfaction towards Local Textile Products with the New Design from Designers in terms of Benefits

\begin{tabular}{lccc}
\hline \multicolumn{1}{c}{ Benefits } & Mean & S.D. & Level of Satisfaction \\
\hline 1. Products can be used in various ways. & 3.84 & 1.012 & High \\
2. Product size is easy to carry. & 3.90 & 0.948 & High \\
3. Product weight is not heavy. & 3.87 & 0.917 & High \\
\hline Total & 3.87 & 0.884 & High
\end{tabular}

Note: A Mean score of 4.21-5.00 refers to the highest level of satisfaction. 3.41-4.20 refers to a high level of satisfaction. 2.61-3.40 refers to a moderate level of satisfaction.1.81-2.60 refers to a low level of satisfaction. 1.00-1.80 refers to the lowest level of satisfaction.
Table 4 revealed that the respondents had been satisfied the local textile products with the new design from designer in terms of benefits at high level with mean score 3.87. Other minor factors in other parts were also at a high level of satisfaction with means scores $3.84,3.90$, and 3.87 respectively. 
Table 5 The Level of Importance of a New Logo according to the Opinions of MICE Travelers

\begin{tabular}{ccc}
\hline Level of Importance of New Logo & Number & Percentages \\
\hline Level 1 & 20 & 20.0 \\
Level 2 & 5 & 5.0 \\
Level 3 & 10 & 10.0 \\
Level 4 & 12 & 12.0 \\
Level 5 & 8 & 8.0 \\
Level 6 & 13.0 \\
Level 7 & 32 & 32.0 \\
\hline Total & 100 & 100.0 \\
\hline
\end{tabular}

Table 5 showed that thirty two respondents $(32 \%)$ ranged the importance of the new logo in Level 7. Twenty respondents or $20 \%$ have given precedence of New Logo in Level 1. Thirteen people or $13 \%$ of respondents ranged the importance of new logo in level 6 , and twelve respondents $(12 \%)$ put priority of the new logo in Level 4. Levels 3, 5, and 2 were ranged by 10,8 , and 5 respondents, respectively. Show in figure 7.

Table 6 The Level of Importance of Public Relations Media according to the Opinions of MICE Travelers

\begin{tabular}{ccc}
\hline Level of Importance of Public Relations Media & Number & Percentages \\
\hline Level 1 & 2 & 2.0 \\
Level 2 & 7 & 7.0 \\
Level 3 & 6 & 6.0 \\
Level 4 & 12.0 \\
Level 5 & 18 & 18.0 \\
Level 6 & 38 & 38.0 \\
\hline Level 7 & 17 & 17.0 \\
\hline Total & 100 & 100.0 \\
\hline
\end{tabular}

Table 6 presented that 38 respondents $(38 \%)$ ranged the importance of Public Relations Media in Level 6. The importance of Public Relations Media was given precedence in Level 5 by 18 people (18\%), followed by Level 7 and 4 with 17 and 12 respondents, respectively. Levels 2, 3, and 1 were ranged by 7, 6, and 2 respondents, respectively. Show in figure 8 .

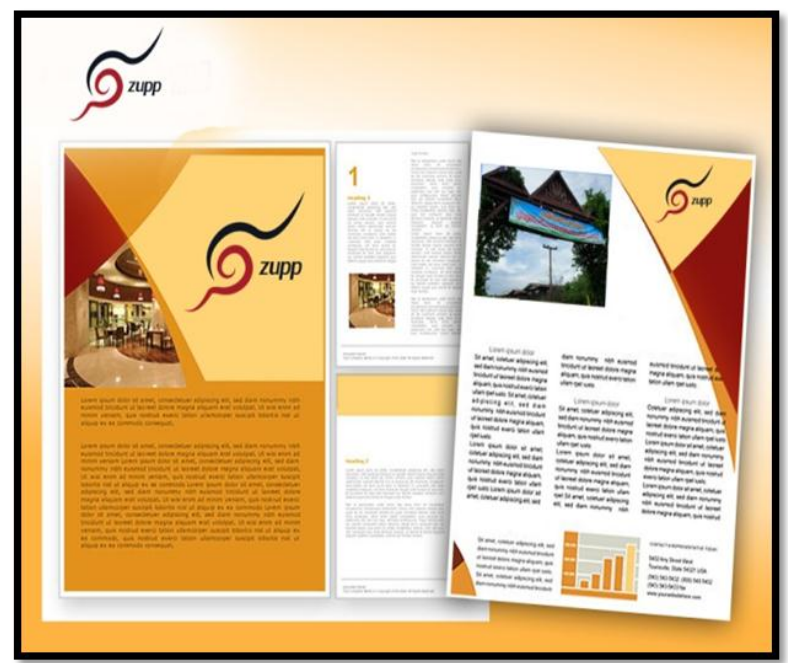

Figure 8 Public Relations Media

Figure 7 The New Logo

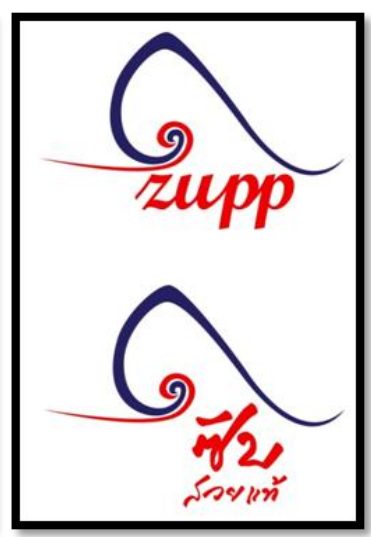


Table 7 The Level of Importance of Souvenir Shops according to the Opinions of MICE Travelers

\begin{tabular}{ccc}
\hline Souvenir Shops & Number & Percentages \\
\hline Level 1 & 6 & 6.0 \\
Level 2 & 14 & 14.0 \\
Level 3 & 18 & 18.0 \\
Level 4 & 15.0 \\
Level 5 & 15 & 26.0 \\
Level 6 & 26 & 10.0 \\
Level 7 & 10 & 11.0 \\
\hline Total & 11 & 100.0 \\
\hline
\end{tabular}

Table 7 showed that 26 respondents $(26 \%)$ ranged the importance of souvenir shop at Level 5. Eighteen respondents or $18 \%$ have given precedence to the souvenir shop in Level 3. 15 people or $15 \%$ of respondents ranged the importance of souvenir shop at Level 4, and 14 respondents (14\%) put the priority of the souvenir shop in Level 2. Levels 7, 6, and 1 were placed by 11,10 , and 6 respondents, respectively. Show in figure 9.

Table 8 The Level of Importance of Stationery according to the Opinions of MICE Travelers

\begin{tabular}{ccc}
\hline Stationery & Number & Percentages \\
\hline Level 1 & 1 & 1.0 \\
Level 2 & 5 & 5.0 \\
Level 3 & 22 & 22.0 \\
Level 4 & 32 & 32.0 \\
Level 5 & 15 & 15.0 \\
Level 6 & 14 & 14.0 \\
Level 7 & 11 & 11.0 \\
\hline Total & 100 & 100.0 \\
\hline
\end{tabular}

Table 8 presented that 32 respondents $(32 \%)$ placed the importance of Stationery in Level 4. The importance of stationery was given precedence in Level 3 by 22 people (22\%), followed by Levels 5 and 6 with 15 and 14 respondents, respectively. Levels 7, 2, and 1 were placed by 11,5 , and 1 respondents, respectively. Show in figure 10.

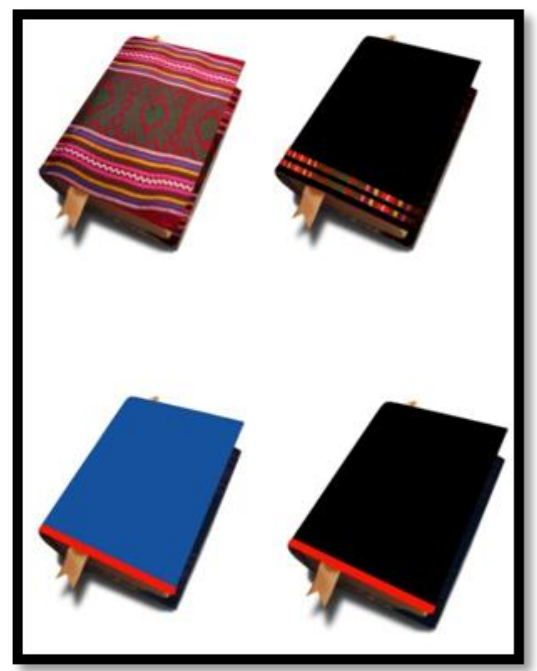

Figure 10 Book Covers

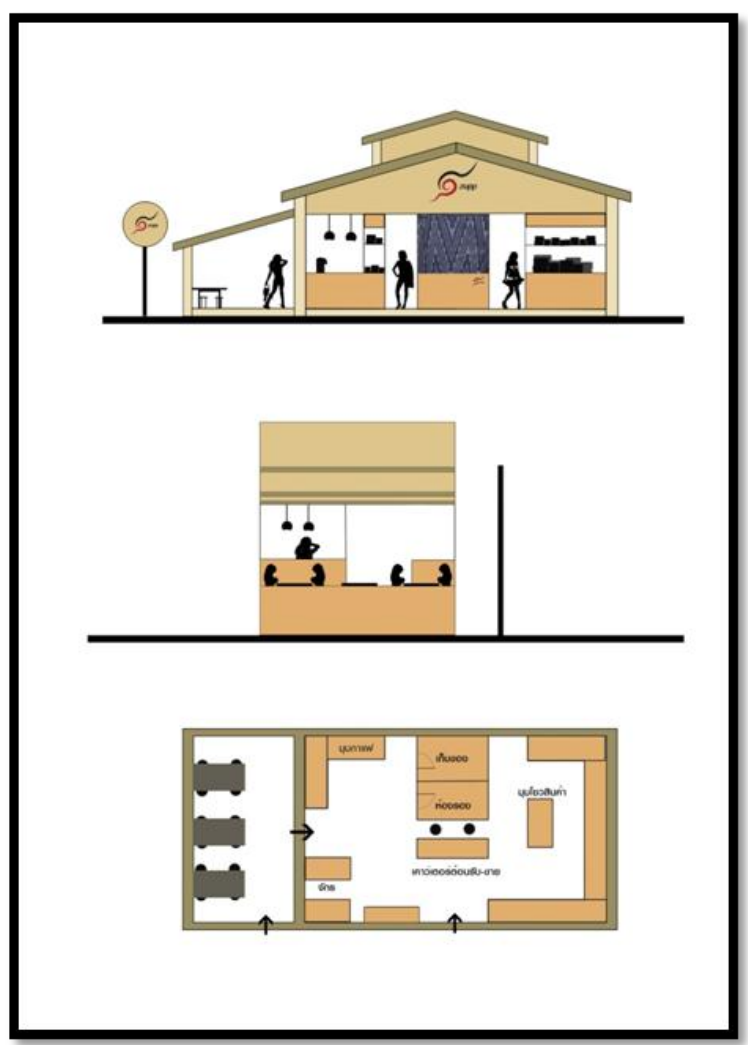

Figure 9 Souvenir Shop (New Design) 
Table 9 The Level of Importance of Accessories according to the Opinions of MICE Travelers

\begin{tabular}{ccc}
\hline Accessory & Number & Percentages \\
\hline Level 1 & 15 & 15.0 \\
Level 2 & 40 & 40.0 \\
Level 3 & 16 & 16.0 \\
Level 4 & 7 & 7.0 \\
Level 5 & 13 & 13.0 \\
Level 6 & 7 & 7.0 \\
Level 7 & 2 & 2.0 \\
\hline Total & 100 & 100.0 \\
\hline
\end{tabular}

Table 9 showed that 40 respondents $(40 \%)$ placed the importance of Accessories in Level 2. Sixteen respondents or $16 \%$ have given precedence of accessories in Level 3. Fifteen people or $15 \%$ of respondents placed the importance of accessories in
Level 1, and 13 respondents $(13 \%)$ put priority of the accessories in Level 5. Seven respondents (7\%) ranged the importance of accessories in Level 4 and in Level 6. Level 7 was placed by 2 respondents. Show in figure 11.

Table 10 The Level of Importance of Suits according to the opinions of MICE Travelers

\begin{tabular}{ccc}
\hline Level of Importance of Suit & Number & Percentages \\
\hline Level 1 & 43 & 43.0 \\
Level 2 & 20 & 20.0 \\
Level 3 & 10 & 10.0 \\
Level 4 & 8 & 8.0 \\
Level 5 & 4 & 4.0 \\
Level 6 & 7 & 7.0 \\
Level 7 & 8 & 8.0 \\
\hline Total & 100 & 100.0 \\
\hline
\end{tabular}

Table 10 presented that 43 respondents $(43 \%)$ had placed the importance of suits in Level 1. The importance of suits was given precedence in Level 2 by 20 people (20\%), followed by Level 3 with 10

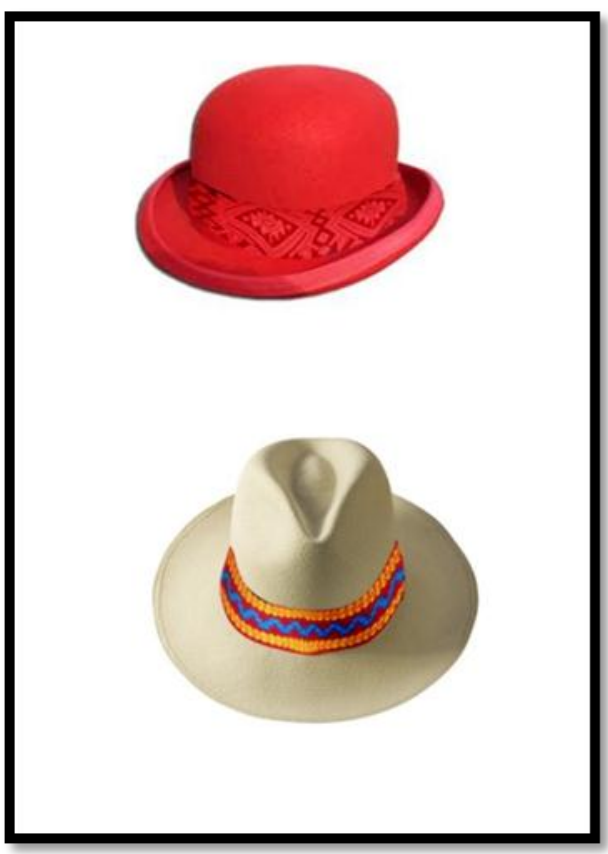

Figure 11 Accessories respondents. 8 respondents $(8 \%)$ placed the importance of suits in Level 4 and in Level 7. Level 6 and Level 5 were placed by 7 and 4 respondents, respectively. Show in figure 12 .

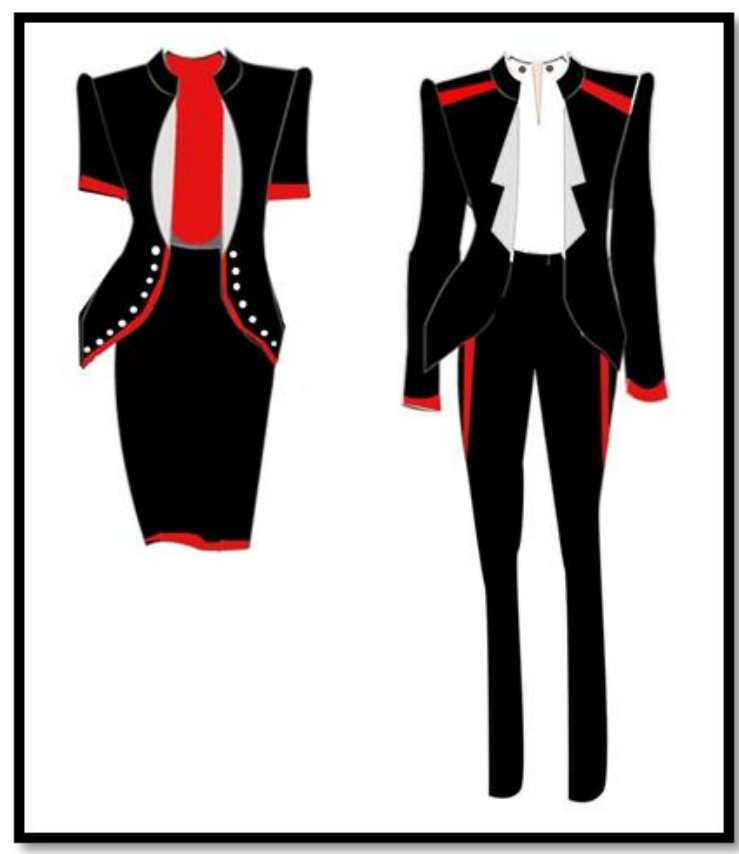

Figure 12: A New Suit Design 
Table 11 Level of Importance of Packaging from the Opinions of MICE travelers

\begin{tabular}{ccc}
\hline Level of Importance of Packaging & Amount & Percentages \\
\hline Level 1 & 15 & 15.0 \\
Level 2 & 10 & 10.0 \\
Level 3 & 18 & 18.0 \\
Level 4 & 12 & 12.0 \\
Level 5 & 16 & 16.0 \\
Level 6 & 10 & 10.0 \\
Level 7 & 19 & 19.0 \\
\hline Total & 100 & 100.0 \\
\hline
\end{tabular}

Table 11 showed that 19 respondents (19\%) placed the importance of packaging in Level 7. 18 respondents or $18 \%$ have given precedence to packaging in Level 3. 16 people or $16 \%$ of respondents placed the importance of packaging in
Level 5, while 15 respondents $(15 \%)$ put priority of the packaging in Level 1. Level 4 was placed by 12 respondents. 10 respondents $(10 \%)$ placed the importance of packaging in Level 2 and in Level 6. Show in figure 13.
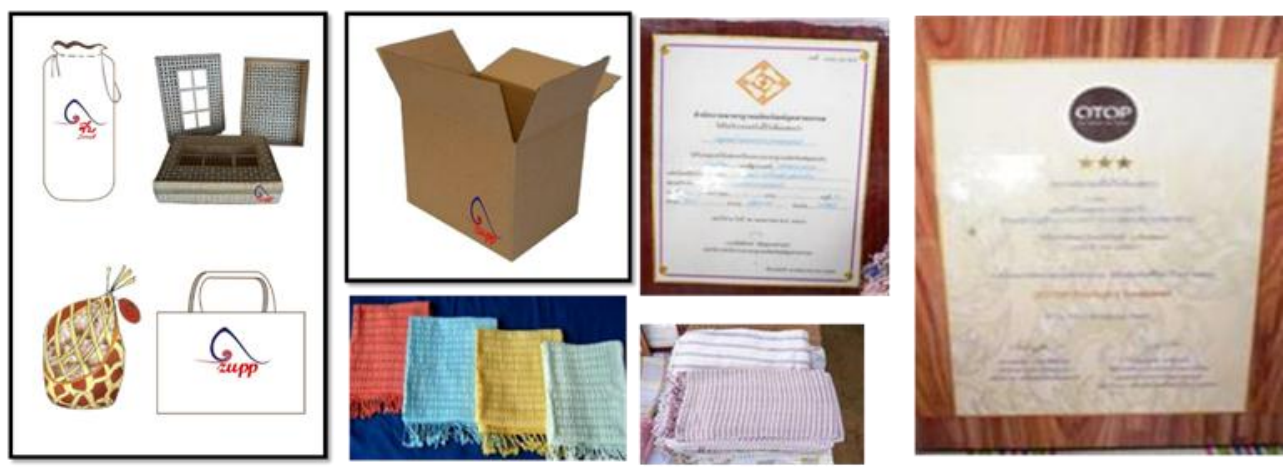

Figure 13 New Packaging Design

The Guidelines of Phutai Ethnic Textiles adapted by using the Advice of Mekong MICE Travelers Project

1. The Community's Understanding of the

2. Documentary \& Field Research re: the authenticity of the Phutai Ethnic Textiles Database

3. Phutai Ethnic Textile Interpretation

4. Co with the Graphic Designer for the product's initiative for Mekong MICE Travelers

5. Phutai Ethnic Textile Products

6. Surveying the Mekong MICE Travelers using Questionnaires

7. Revising the product's concept \& design

\section{REFERENCES}

Association for Heritage Interpretation, 1975, Britain's Heritage (United Kingdom: Association for Heritage Interpretation)

Good, C. V., 1973. Dictionary of Education (New York: Mc Graw Hill Book)

Gove, P. B., 1963., Webster's third new international dictionary of the English language (Springfield, Mass: G\&C Merriam)

Julaju, 2008, Phutahi Cultural, Date of access:
12/02/2016. http://hs4cjn.blogspot.com/2008/07/blog -post.html

Ministry of University Affairs, 1998, Thai Higher Educaation in Brief (Bangkok: University Printing House)

Pook, 2002, The type of fabric, Date of access: 12/02/2016. http://phathai.tripod.com/html/Phathail _3_2.html

Textile Development Center, 2011, Textiles: Technical conquer the future, Date of access: 18/01/2016. http://www.thaitextile.org/tdc/?page _id=711

The Institute for Small and Medium Enterprises Development, 2003, Thailand Invited to a New Year Gifts with the OTOP-SMEs (Bangkok: Corporate Communication, Office of the Director)

The Thai Silk Company, 1951, Thai Silk Products, Date of access: 12/01/2016. http://www.jimthompson fabrics.com/products

The Office of the National Economic and Social Development Board, 2006, Cluster Mapping, Date of access: 19/02/2016. http://cm.nesdb.go.th/choose province20.asp

Tourism Authority of Thailand, n.d., Phutahi Cultural, Date of access: 24/03/2016. http://thai. tourismthailand.org 
Rohwer, G., 2010, Models in Statistical Social Research (New York: Routledge).

Silpakorn University, 2001, Local Textiles (Bangkok: Silpakorn University).

Tilden, F., 1957, Interpreting Our Heritage (North Carolina: University of North Carolina Press)
Woodikarn, K., 2001, Life, Faithful and Textile: Inherited knowledge of textiles Mae Jam District Chiang Mai Province. Sekhiyadhamma, 11(47), 1019.

Wuttatrakul, W. and Phanyura, Y., 1994, Textile and Thai Lifestyle (Bangkok: Office of the National Culture Commission). 